\title{
Correlation of Oxidized-LDL, Resistin and Interleukin-1 Beta in Centrally Obese Men
}

\author{
Tri Nevita Margareth Panjaitan ${ }^{1,2, *}$, Marita Kaniawati ${ }^{1,3}$, Ilhamjaya Patellongi ${ }^{4}$ \\ ${ }^{1}$ Postgraduate Program in Clinical Biochemistry, Hasanuddin University, Jl. Perintis Kemerdekaan Km.10, Makassar, Indonesia \\ ${ }^{2}$ Prodia Occupational Health Institute, Jl. Kramat VI No.18, Jakarta, Indonesia \\ ${ }^{3}$ Prodia Clinical Laboratory, Jl. Cisangkuy No.2, Bandung, Indonesia \\ ${ }^{4}$ Faculty of Medicine, Hasanuddin University, Jl. Perintis Kemerdekaan Km.10 Makassar, Indonesia \\ *Corresponding author. E-mail: trinevt@gmail.com
}

\section{Abstract}

B ACKGROUND: Obesity is one of serious health problems, which increases the risks of cardiovascular disease, type 2 diabetes mellitus, and cancers. It is strongly associated with changes in the physiological function of adipose tissue, leading to altered secretion of adipokines and activation of inflammatory signaling pathways. This study was aimed to investigate the correlation of resistin, interleukin-1 beta (IL-1 $\beta$ ), and oxidized low-density lipoprotein (OxLDL) in centrally obese men.

METHODS: The research was conducted with a crosssectional design involving 68 centrally obese men aged 31 to 60 years old, with waist circumference (WC) $>90 \mathrm{~cm}$. All subjects fulfilled the exclusion criteria. Anthropometric parameters, creatinine, estimated glomerular filtration rate (eGFR), serum glutamic oxaloacetic transaminase (SGOT), serum glutamic-pyruvic transaminase (SGPT), and highsensitivity C-reactive protein (hs-CRP) were measured. Serum concentrations of resistin, IL- $1 \beta$ and OxLDL were measured by enzyme-linked immunosorbent assay.

RESULTS: The study results showed there was a significant correlation of WC-OxLDL $(\mathrm{r}=0.235 ; p=0.030)$ and some correlation of WC-resistin $(\mathrm{r}=0.201 ; p=0.050)$. However, we observed no significant correlation of IL-1 $\beta$-OxLDL $(\mathrm{r}=0.042 ; p=0.369)$, resistin-OxLDL $(\mathrm{r}=-0.072 ; p=0.285)$ and WC-IL-1 $\beta(\mathrm{r}=-0.042 ; p=0.367)$.

CONCLUSION: Our data show a relationship between WC and OxLDL, but the mechanism does not appear to be directly related to resistin or IL- $1 \beta$.

\section{Abstrak}

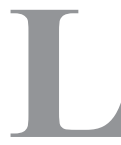

ATAR BELAKANG: Obesitas merupakan salah satu masalah kesehatan yang cukup serius, yang dapat meningkatkan risiko penyakit kardiovaskular, diabetes melitus tipe 2 , kanker, dan lainnya. Hal ini sangat erat kaitannya dengan perubahan fungsi fisologis jaringan adiposa yang menyebabkan perubahan sekresi adipokin dan aktivasi jalur sinyal inflamasi. Penelitian ini bertujuan untuk menyelidiki kontribusi resistin, interleukin-1 beta (IL-1 $\beta$ ), dan low-density lipoprotein teroksidasi (OxLDL) pada pria obesitas sentral.

METODE: Penelitian ini dilakukan dengan desain potong lintang yang melibatkan 68 subyek pria obesitas berusia 31 sampai 60 tahun, dengan lingkar pinggang (LP) $>90$ $\mathrm{cm}$. Semua subyek memenuhi kriteria eksklusi. Dilakukan pengukuran terhadap parameter antropometri, kreatinin, laju filtrasi glomerulus, Serum glutamat oksaloasetat transaminase, serum glutamat piruvat transaminase, dan high-sensitivity $C$-reactive protein. Konsentrasi serum resistin, IL-1 $\beta$ dan oxLDL diukur dengan metode enzymelinked immunosorbent assay.

HASIL: Penelitian ini menunjukkan ada hubungan yang signifikan antar LP-OxLDL ( $\mathrm{r}=0,235 ; p=0,030)$, LP-resistin $(\mathrm{r}=0,201 ; p=0,050)$. Namun, tidak terdapat korelasi yang signifikan antara IL-1 $\beta$-oxLDL $(\mathrm{r}=0,042 ; p=0,369)$, resistinoxLDL $(\mathrm{r}=-0,072 ; p=0,285) \quad$ dan LP-IL-1 $\beta \quad(\mathrm{r}=-0,042$; $p=0,367)$.

KESIMPULAN: Penelitian ini menunjukkan hubungan antara lingkar pinggang dan progresi OxLDL, namun mekanismenya tidak melalui jalur resistin ataupun IL-1 $\beta$ 
KEYWORDS: resistin, IL-1 $\beta$, OxLDL, atherosclerosis

Indones Biomed J. 2013; 5(1): 59-64 secara langsung.

KATA KUNCI: resistin, IL-1 $\beta$, OxLDL, aterosklerosis

\section{Introduction}

Obesity is a serious health problem that increases the risk not only of cardiovascular disease and type 2 diabetes mellitus (T2DM) but also of various types of cancer. Obesity is strongly associated with changes in the physiological function of adipose tissue, leading to insulin resistance, chronic inflammation, and altered secretion of adipokines.(1) Obesity is a condition in which there is excessive accumulation of body fat.(2) Obesity-associated inflammation occurs as a result of immune cell infiltration of the adipose tissue and increased production of proinflammatory cytokines. These changes negatively affect normal adipocyte functions such as triglyceride storage and lipolysis, leading to high circulating levels of free fatty acids and ectopic lipid accumulation. In addition, elevated levels of pro-inflammatory cytokines, including interleukin (IL)$1 \beta$, IL-6, and tumor necrosis factor (TNF)- $\alpha$, reduce insulin sensitivity, which can lead to the development of T2DM if insulin production by the pancreatic $\beta$ cells is not sufficiently increased. Although it has been recognized for some time that pro-inflammatory cytokines inhibit insulin signaling, the molecular mechanisms that trigger inflammation and cytokine production in obesity are not well understood.(3)

Obesity-related danger signals, such as palmitate, ceramide, high glucose concentrations, islet amyloid polypeptide deposition, defective autophagy, or mitochondrial dysfunction may lead to the generation of reactive oxygen species (ROS) and subsequent activation of the nucleotide-binding oligomerization domain, leucine rich repeat and pyrin domain containing (NLRP)3 inflammasome in adipocytes, pancreatic islet cells, or infiltrating macrophages present in these tissues. NLRP3 inflammasome activation promotes the cleavage and activation of Caspase-1, resulting in the secretion of IL$1 \beta$, a pro-inflammatory cytokine that negatively affects adipocyte differentiation, inhibits insulin signaling, and has a cytotoxic effect on insulin-producing pancreatic $\beta$ cells. Identification of a connection between obesity, the inflammasome, and insulin resistance links inflammasome activation with metabolic tissue dysfunction, which may contribute to the pathogenesis of T2DM, and other diseases associated with obesity-induced inflammation.(3)

IL-1 $\beta$, a proinflammatory cytokine with a variety of activities, is strongly induced in monocytes by direct contact with stimulated $\mathrm{T}$ lymphocytes. Both these cells are involved in immunoinflammatory diseases (such as rheumatoid arthritis, multiple sclerosis, and systemic lupus erythematosus) and atherosclerosis. IL-1 $\beta$ has been shown to have important effects on the cell types that constitute atherosclerotic lesions.(4)

Resistin belongs to a family of cysteine-rich secretory proteins called resistin-like molecules or is found in inflammatory zones (FIZZ) proteins. In rodents, resistin is derived almost exclusively from fat tissue, and adipose expression and serum levels are elevated in models of obesity and insulin resistance. In contrast to rodents, in humans resistin is expressed primarily in inflammatory cells. Resistin expression in human monocytes was markedly increased by treatment with endotoxin and proinflammatory cytokines. (5) Resistin was found with relevance to the incidence of inflammation and inflammation-related diseases such as atherosclerosis and arthritis.(6)

Experimental studies have shown that the oxidative conversion of low-density lipoproteins (LDL) to oxidized (OxLDL) is considered to be a key event in the biological process that initiates and accelerates the development of the early atherosclerotic lesion, the fatty streak and the unstable and plaque rupture.(7)

Increasing prevalence of obesity has motivated some researchers to do studies to prevent or overcome the negative effects of the disease. It has been known that obesity correlates with atherosclerosis and cardiovascular disease which cause mortality in many countries including Indonesia. This study aimed to investigate the role of resistin and IL-1 $\beta$ in pathomechanism of atherosclerosis in centrally obese men.

\section{Methods}

\section{Subjects}

Participants were recruited from the community in Jakarta. The sample population comprised centrally obese men aged 30 to 60 years. WC $>90 \mathrm{~cm}$ was determined by 
measuring the waist between the lower rib and iliac crest. Interview was done to gather information on medical history, present condition, and drugs consumption. Other characteristics i.e. smoking and alcohol consumption habits and medication were investigated by individual interviews using a structured questionnaire. Subjects with estimated glomerular filtration rate $(\mathrm{eGFR})<60 \mathrm{~mL} /$ minute or serum glutamic oxaloacetic transaminase (SGOT)) / serum glutamic-pyruvic transaminase (SGPT) more than 2 times the normal value or high-sensitivity C-reactive protein (hsCRP) $\geq 10 \mathrm{mg} / \mathrm{L}$ were excluded. This study was approved by the ethics committee of Hasanuddin University Faculty of Medicine (registered number UH1303119), and written informed consent was obtained from each subject.

\section{Blood collection and biochemical analysis}

Blood samples were collected in the morning after overnight fasting. Venous blood was collected, centrifuged, and the separated serum was frozen immediately at $-20^{\circ} \mathrm{C}$. Serum levels of SGOT, SGPT, creatinine, and hsCRP were assayed using autoanalyzer Cobas (Roche Diagnostics). Circulating resistin, IL-1 $\beta$ and OxLDL levels were measured using a commercially available enzyme-linked immunosorbent assay (ELISA) (resistin: Quantikine, catalogue no. DRSN00; IL-13: Quantikine, catalogue no. HSLB00C; OxLDL: Mercodia, catalog no. 10-1143-01).

\section{Statistical analysis}

Statistical analysis was performed using SPSS for Windows version 16.0 (USA, SPSS 101 Inc.). Data were analyzed by Spearman and Pearson bivariate and partial correlation to evaluate the relationships between $\mathrm{WC}$, resistin serum, IL-1 $\beta$, and OxLDL. All values were expressed as mean \pm standard deviation (SD), unless otherwise specified. Hypothesis testing was two-tailed at a significance level of 0.05 .

Table 1. Subjects Characteristics.

\begin{tabular}{lcccc}
\hline \multicolumn{1}{c}{ Characteristics } & Mean \pm SD & Min & Max & Median \\
\hline Age $($ year $)$ & $45.960 \pm 8.169$ & 31 & 60 & 45.500 \\
Height $(\mathrm{cm})$ & $166.200 \pm 5.288$ & 150 & 176 & 166 \\
Weight $(\mathrm{kg})$ & $79.670 \pm 9.663$ & 62 & 115 & 77 \\
WC $(\mathrm{cm})$ & $99.220 \pm 6.788$ & 91 & 130 & 99 \\
DBP $(\mathrm{mmHg})$ & $83.600 \pm 14.295$ & 60 & 120 & 80 \\
SBP $(\mathrm{mmHg})$ & $124.260 \pm 18.724$ & 90 & 170 & 120 \\
BMI $\left(\mathrm{kg} / \mathrm{m}^{2}\right)$ & $28.820 \pm 3.093$ & 23.58 & 41.23 & 28.820 \\
SGPT $(\mathrm{U} / \mathrm{L})$ & $32.290 \pm 17.557$ & 10 & 122 & 27 \\
SGOT $(\mathrm{U} / \mathrm{L})$ & $22.980 \pm 8.010$ & 12 & 52 & 21 \\
Creatinine $(\mathrm{mg} / \mathrm{dL})$ & $0.871 \pm 0.124$ & 0.59 & 1.20 & 0.860 \\
eGRF $\left(\mathrm{mL} / \mathrm{min} / 1.73 \mathrm{~m}^{2}\right)$ & $102.080 \pm 11.665$ & 67 & 135 & 103 \\
hs-CRP (mg/L) & $2.950 \pm 2.260$ & 0.30 & 9.50 & 2.400 \\
IL-1 $\beta(\mathrm{pg} / \mathrm{mL})$ & $0.050 \pm 0.043$ & 0.01 & 0.28 & 0.046 \\
Resistin $(\mathrm{ng} / \mathrm{mL})$ & $8.400 \pm 3.551$ & 2.97 & 16.74 & 7.290 \\
OxLDL $(\mathrm{U} / \mathrm{L})$ & $269.080 \pm 23.805$ & 198.60 & 270.400 \\
\hline
\end{tabular}

$\mathrm{DBP}=$ diastolic blood pressure; $\mathrm{SBP}=$ systolic blood pressure 
Table 2. Correlation between OxLDL and Other Variables

\begin{tabular}{lcccc}
\hline & \multicolumn{4}{c}{ OxLDL } \\
\cline { 2 - 5 } Variable & \multicolumn{2}{c}{ Bivariate } & \multicolumn{2}{c}{ Partial } \\
\cline { 2 - 5 } & $\mathbf{r}$ & $\boldsymbol{p}$ & $\mathbf{r}$ & $\boldsymbol{p}$ \\
\hline Age & 0.260 & 0.032 & 0.251 & 0.022 \\
WC & 0.242 & 0.046 & 0.235 & 0.030 \\
IL-1 $\beta$ & 0.058 & 0.636 & 0.042 & 0.369 \\
Resistin & -0.028 & 0.828 & -0.072 & 0.285 \\
\hline
\end{tabular}

Table 3. Correlation between Resistin, IL-1 $\beta$ and WC

\begin{tabular}{ccccc}
\hline & \multicolumn{4}{c}{ WC } \\
\cline { 2 - 5 } Variable & \multicolumn{2}{c}{ Bivariate } & \multicolumn{3}{c}{ Partial } \\
\cline { 2 - 5 } & $\mathbf{r}$ & $\boldsymbol{p}$ & $\mathbf{r}$ & $\boldsymbol{p}$ \\
\hline Resistin & 0.275 & 0.010 & 0.201 & 0.050 \\
IL-1 $\beta$ & 0.079 & 0.256 & -0.042 & 0.367 \\
\hline
\end{tabular}

\section{Results}

\section{Clinical characteristics of subjects}

The anthropometric and clinical characteristics of the participants are shown in Table 1. The subjects comprised centrally obese men aged $46 \pm 8.17$ (range: $31-60$ ) years and the mean WC was $99 \pm 6.78$ (range: $91-130) \mathrm{cm}$.

\section{Correlation between waist circumference and OxLDL}

Results of the bivariate and partial correlation analysis of WC, resistin, IL-1 $\beta$ and OxLDL are presented in Table 2. The circulating OxLDL tended to correlate positively with $\mathrm{WC}(\mathrm{r}=0.235)$ and the correlation was significant $(p=0.030)$. IL-1 $\beta$ also had positive correlation with OxLDL, but the correlation was not significant $(\mathrm{r}=0.042$ dan $p=0.369)$. The correlation of resistin and OxLDL was negative but not significant $(\mathrm{r}=-0.072$ dan $p=0.285)$.

\section{Correlation between resistin, interleukin-1 beta and WC}

Table 3 shows the correlation between resistin, IL-1 $\beta$ and WC. The partial correlation analysis of $\mathrm{WC}$ and resistin shows that both have a significant positive correlation $(\mathrm{r}=0.201 ; p=0.050)$, while the circulating IL-1 $\beta$ tended to correlate negatively with $\mathrm{WC}$, but the correlation was not significant $(\mathrm{r}=-0.042 ; p=0.367)$.

\section{Discussion}

This study used bivariate and partial correlation analysis. The partial correlation was done to prevent ambiguous correlation due to some variables, which is called a pure correlation. WC and OxLDL show positive and significant correlation $(\mathrm{r}=0.235 ; p=0.030)$. It shows that the greater the WC the more the OxLDL concentration increased. This result agrees with the result of the study by Weinbrenner et al. which showed $\mathrm{WC}>102 \mathrm{~cm}$ in men and $\mathrm{WC}>88$ $\mathrm{cm}$ in women with body mass index $(\mathrm{BMI})=25.0-29.9$ and $\mathrm{BMI}>30$ had strong correlation with elevated OxLDL concentration. Holvoet in 2001 proved that BMI was one of strong predictors in elevating OxLDL concentration.(8,

9) The statistic analysis showed that OxLDL had positive correlation with IL-1 $\beta$ but not significant $(\mathrm{r}=0.042, p=0.369$ ) and a negative non significant correlation with resistin $(\mathrm{r}=-$ $0.072 ; p=0.285$ ). 
Several previous studies have been done to investigate correlation between OxLDL and adipokines, but none of them focused on correlation with resistin. This study had the hypothesis that there might be correlation between resistin and OxLDL. The analysis showed that OxLDL and resistin had negative correlation, but not significant. Gazbar et al. observed that resistin was significantly more abundant in atherosclerotic lesions $(\mathrm{r}=0.822 ; p<0.01)$. This correlation was a novel finding though the correlation between resistin and OxLDL was still unclear. It could happen due to proinflammatory characteristic of resistin in human which is a promising biomarker. The different result found in this study could be due to different characteristics of the study subject. Gazbar et al. used obese men with diabetic history but this study used obese men with no diabetic history. This might occur due to the fact that diabetic patients have insulin resistance in which resistin has important effect in that condition.(10)

The proatherogenic characteristic of IL-1 is due to cytokine's ability to modulate adhesion cell and monocyte filtration to subendothelium. Kirii et al. pointed out that the absence of IL-1 $\beta$ decreased atherosclerosis progression in mice Apolipoprotein E (ApoE), which might exist because of decreased expression of vascular cell adhesion molecule-1 (VCAM-1) and monocyte chemotactic protein-1 (MCP-1) in aorta.(4) This process might attract monocytes into the artery intima. The adhesion that continues with differentiation into macrophages and forms foam cells, is the key of atherogenesis phase.(11) According to the study by Mojtaba et al, IL-1 $\beta$ serum concentration in obese men is higher than that in non obese men. Nevertheless, not many studies have been done to analyze the role and correlation of IL-1 $\beta$ in atherosclerosis progression.(12)

Resistin is a proinflammatory cytokine which might have an important role in atherosclerosis and other inflammatory diseases. A recent study has shown that resistin will make worst the atherosclerosis condition by stimulating monocytes, endhotelial cells, and vascular smooth muscle cells to induce vascular inflammation.(8)

From our study results we can see that WC has mild correlation with resistin $(\mathrm{r}=0.201 ; p=0.050)$. It shows that elevated WC in men has some correlation with chronic inflammation process, characterized by positive correlation with inflammation biomarker. Previous studies have proven it already that resistin has positive correlation with body fat. It indicates resistin's elevating expression is a result of adipocyte differentiation.(13)

Results of our statistical tests have shown a negative correlation tendency, but not significant between WC and IL$1 \beta(\mathrm{r}=-0.042, p=0.367)$, even it showed reverse correlation.
It means as there is decrease of concentration of IL- $1 \beta$, there is increase of the WC. However, not many studies support this result.

\section{Conclusion}

According to results of our study, we conclude that there is no significant increase of resistin or significant decrease of IL-1 $\beta$ in obese men. Regarding this fact, the possible pathways need to be further investigated.

\section{Acknowledgement}

This study was supported by the Prodia Education and Research Institute. We thank for the invaluable supports given to this study.

\section{References}

1. Kruijsdijk RCM, Wall EVD, Visseren FLJ. Obesity and cancer: the role of dysfunctional adipose tissue. Cancer Epidem Biomar. 2009; 18: 2569-78.

2. Soegondo AW, Setiyohadi B, Alwi I, Simadibrata M, Setiati S. Buku Ajar Ilmu Penyakit Dalam. 4th ed.Jakarta: Pusat Penerbitan Departemen Ilmu Penyakit Dalam Fakultas Kedokteran Universitas Indonesia; 2007.

3. R\&D Systems [http://www.rndsystems.com/ index.aspx]. ObesityInduced Activation of the Nlrp3 Inflammasome Promotes Insulin Resistance; 2013 [updated 2013; cited 2013]. Available from: http:// www.rndsystems.com/cb_detail_objectname_cb11i2_obesity_ induced_activation_Nlrp3.aspx

4. Kirii H, Niwa T, Yamada Y, Wada H, Saito K, Yoichiro. Lack of Interleukin- $1 \mathrm{~b}$ decreases the severity of atherosclerosis in ApoEdeficient mice. Arterioscler Thromb Vasc Biol. 2003; 23: 656-60.

5. Reilly PM, Lehrke M, Wolfe ML, Rohatgi A, Lazar MA, Rader DJ. Resistin is an inflammatory marker of atherosclerosis in humans. J Am Heart Assoc. 2005; 111: 932-9.

6. Pang $\mathrm{S}$ and Le $\mathrm{Y}$. Role of resistin in inflammation and inflammationrelated diseases. Cell Mol Immunol. 2006; 1: 29-34.

7. Mercodia Oxidized LDL ELISA Kit Insert. Enzyme immunoassay. Mercodia Catalogue. 2004; No. 10-1143-01.

8. Weinbrenner T, Schroder H, Escurriol V, Fito M, Elosua R, Vila $\mathrm{J}$, et al. Circulating OxLDL is associated with increased waist circumference independent of body mass index in men and women. Am J Clin Nutr. 2006; 83: 30-5.

9. Holvoet P, Mertens A, Verhamme P, Bogaerts K, Beyens G, Verhaeghe $\mathrm{R}$, et al. Circulating oxidized LDL is a useful marker for identifying patients with coronary artery disease. Arterioscler Thromb Vasc Biol. 2001; 21: 844-8.

10. Gazbar S, Fethi BS, Abdelmagid T, Chiheb BRM, Omrane B. Relationship between oxidized-LDL and resistin levels in obese diabetic subject. J Basic Appl Sci Res. 2013; 4: 313-7. 
11. Vicenova B, Vopaslensky V, Burysek L, Pospisek M. Emerging role of interleukin-1 in cardiovascular diseases. Physiol Res. 2009; 58: 481-98.

12. Mojtaba E, Mahdi K, Mehdi KJR, Amir S. Serum interleukin-1 beta plays an important role in insulin secretion in type II diabetic. $\mathrm{J}$ Biosci 2011; 32: 93-9.

13. Kusminski CM, McTernan PG, Kumar S. Role of resistin in obesity, insulin resistance and type II diabetes. Clin Sci 2005; 109: 243-56. 